\title{
Om Grundtvigs Sang-Værk
}

\section{Af Henning Høirup}

Nikolaj Frederik Severin Grundtvig: Sang-Vark til den danske Kirke (bind 1, 1-2), Sang-Vark til den danske Kirke-Skole (bind 2). Salmer og kristelige Digte 1809-43 (bind 3, 1-2), 1844-55 (bind 4, 1-2) og 1855-72 (bind 5,1-2). G.E.C. Gads Forlag 1982-84.

I anledning af 200-året for Grundtvigs fødsel har Gads Forlag som bekendt udsendt et fotografisk optryk af den hidtil mest fuldstændige og filologisk korrekte udgave af Grundtvigs SangVark bind I-V (Det danske Forlag 1944-51). Bind VI, der først kom i 1956-64 med varianter og noter til de fem tekstbind, er aldeles nødvendigt til ethvert studium af salmerne. Desværre medtages det ikke i "jubilæumsoplaget ", fordi det - som Christian Thodberg skriver i forordet - vil kræve en mangeårig indsats at revidere det ved inddragelse af de resultater, som er indvundet gennem forskningen $\mathrm{i}$ de forløbne tyve år. Der foreligger dog et restoplag af kommentarbindet, der kan fås ved henvendelse til Grundtvig-Selskabets kontor i Vartov.

Ved fremkomsten blev dette store udgiverarbejde (i det følgende betegnet GSV) ikke anmeldt i Grundtvig-Studier. Det er derfor rimeligt at gøre det nu.

Det lovede ikke godt, at de fem udgiveres forord i 1944 bragte en forkert oplysning om Sang-Værkets forhistorie, en fejl, der beklageligvis ikke er rettet nu i 2. oplag: "De første fire bind er senere flere gange optrykt. "Imidlertid er både bind 3 og 4 kun udgivet een gang (se Steen Johansen: Bibliografi over N.F.S. Grundtvigs Skrifter II s. 115).

Men chocket over denne lapsus overvindes, såsnart man tager udgaven i brug. Der er arbejdet med myreflid af udgiver-holdet: Th. Balslev, Ernst J. Borup, Uffe Hansen, Ejnar Skovrup og Magnus Stevns. Den sidstnævnte var blandt sin tids litteraturhistorikere den kyndigste kender af Grundtvigs salmer (se bøgerne "Grundtvig-Manuskripter", 1936 og "Fra Grundtvigs Salmeværksted ", 1950) og han forestod derfor arbejdet med håndskrifterne til sin død i 1949, hvorefter Uffe Hansen overtog og - med 
omhu - bragte det til afslutning. Arbejdet gav ham mange impulser til de sidste to bind af hans hovedværk: Grundtvigs Salmedigtning (I-III, 1937, 1951 og 1966). Iøvrigt synes udgiverne at have virket $\mathrm{i}$ anonymt fællesskab. Det oplyses ikke, hvilke afsnit de enkelte har ansvar for.

I fremlæggelsen af teksterne adskiller GSV sig fra de tidligere udgaver af Sang-Værket siden Grundtvigs død. I disse havde man nemlig fulgt det udgiverprincip, som Svend Grundtvig frimodigt knæsatte i sin udgave af faderens Poetiske Skrifter (bind I, 1880, s. xviii): "Retskrivningen og Læsetegnene høre Udgiveren til, ligesom han ogsaa har forbeholdt sig Raadighed over Udhævelser".

Denne sproglige nutidiggørelse er jo, brugt med måde, forsvarlig i salme- og sangbøger, men må i vor tid anses for utilstedelig i en komplet, dokumentarisk udgivelse. Til forsvar for Svend Grundtvig må anføres, at han havde sæde i Den Grundtvigske Salmefond, der bekostede udgivelserne; han ville fremme fondens folkelige formål: "Befordring af Psalmesang i Kirkerne, Skolerne og Hjemmene ". Følgelig udkom 3.-5. udgave af SangVærk I-II med moderniseret stavemåde og hyppig udeladelse af Grundtvigs mange spatieringer. Det samme galder de tre sidste bind af Grundtvigs salmedigtning, der efter hans død blev udgivet af $J$. Kristian Madsen i nært samarbejde med Svend Grundtvig: "Kirke-Aaret i Salme-Sang " (1873), "Kristen-Livet i SalmeSang " (1875) og "Efterslæt af Grundtvigs Salmesang" (1881).

Udgiverne af GSV har helt forladt denne moderniseringsmetode og følger med rette det spor, som allerede Holger Begtrup klart markerede i forordet til sin fortrinlige udgave af Grundtvigs Udvalgte Skrifter (bind I, 1904): "Hvert Skrift bliver trykt med sin oprindelige Retskrivning, og i det hele vil jeg stræbe at gøre denne Udgave saa nøjagtig som muligt, for at den ved Siden af sin Betydning som Folkelæsning skal kunne hævde sin Værdighed som et litterært Hovedværk, der taaler videnskabelig Prøvelse."

J.Kr. Madsens udgiverarbejde, der bragte omkring 400 utrykte salmer for dagens lys, var trods den omtalte mangel såre prisværdigt - især p.gr. af hans teksthistoriske undersøgelser ("Bidrag til Grundtvigs Salmedigtnings Historie" i "Efterslæt" s. 653-884). Han gør omhyggeligt rede for salmernes tilblivel- 
sestid og forholdet mellem håndskrifter og tryk, med oplysning om alle af Grundtvig foretagne ændringer. Denne variantsamling kom, i de fleste tilfælde, nær til den tilstræbte fuldstændighed hvad læsemåder angår (men, som nævnt ikke mht. stavemåder). GSV-udgaven har derfor $i$ bind VI sat en ære $\mathrm{i}$ at videreføre, revidere og øge Madsens teksthistorie. Yderligere bringes nyttige henvisninger til de bibelsteder, Grundtvig benytter, og til litteratur om de pågældende salmer samt "efter Forslag fra Det danske Sprog- og Litteraturselskab « forklaring af dunkle steder i salmerne. Endelig er der s. 515-27 en - alt for kort - ordforklaringsliste.

GSV I genudgiver originaludgaven af Sang-Værk I 1837, altså ikke den af Grundtvig selv foretagne "Anden uforandrede Udgave" 1868, hvor han $\mathrm{i}$ forordet skriver: "Uagtet endeel Ord hist og her er forandrede, er dog derved hverken fremkommet andre Sange eller anden Mening". Det sidste holder ikke helt stik. Både form og mening ændres i flere tilfælde, især i de salmer, der var kommet i brug i Vartov og andre steder, og som Grundtvig derfor i særlig grad stræbte at forbedre - oftest med held. Denne Grundtvigs sidste redaktion af Sang-Værk blev betragtet som autoritativ og fulgt $\mathrm{i}$ de følgende udgaver 1873, 1883 og 1890.

Det var $\mathrm{i}$ forrige århundrede almindeligt ved genudgivelser at respektere forfatterens "sidste vilje». Man bragte i regelen værkerne i "den sidste af Digteren selv besørgede Udgave", som endnu Carl S. Petersen skriver (hvilket han også selv gjorde i sin udgave af Paludan-Müllers Poetiske Skrifter 1909). På denne tid begyndte ellers nogle udgivere at foretrække digternes originalversion. Således valgte Begtrup førsteudgaven af "Optrin af Kæmpelivets Undergang i Nord " fra 1811, mens Svend Grundtvig (i Poetiske Skrifter fra 1880) typisk for sin tid havde valgt faderens andenudgave fra 1861. I vort århundrede afløstes i stigende grad ærbødigheden for "sidste hånd på værket" af ærefrygten for det oprindelige digterværk, således i Holbergselskabets klassikerudgaver ("Danmarks Nationallitteratur»), dog med een undtagelse, Poul Tuxens udgave af Sibbern: "Gabrielis's Breve" (1927). Sibbern udgav 1. del i 1826, mens 2. del først kom 1850. Samlet udkom begge dele i 1851, og heri indførte Sibbern "de smaa Ændringer, som den fornyede Gennemtænkning af Stoffet har ført ham til, uden at disse smaa Indgreb paa 
noget Punkt gaar ud over Originalens Friskhed «. Sibbern ønskede at præge de to dele af sin "Hjertebog" (Vilh. Andersen) som en enhed og bragte derfor teksten $i$ den 24 år ældre 1 . del $i$ samklang med 2. del. Det er hævet over enhver tvivl, at Grundtvig havde samme intention som sin ungdomsven, da han endelig i 1868-70 fik midler til samtidig at genudgive Sang-Værk I og færdiggøre 2. bind, "Sang-Værk til den danske Kirke-Skole", hvis førsteudgave gik i stå allerede efter udsendelsen af 2 . hefte.

Da Grundtvig ville, at de to bind skulle fremtræde som et hele, udgav han dem nu med samme hovedtitel: Psalmer og aandelige Sange, Første Deel, 1868, og Anden Deel, 1870. Hans revision af Sang-Værk I skyldes ønsket om sprogligt at samstemme det med Sang-Værket til skolen, og den har ikke forringet, men forbedret dets kvalitet, som jeg nedenfor skal eftervise.

Som eksempel på Grundtvigs rettelser af et enkelt ord i en salme kan nævnes nr. 24: "Var I ikke Galilæer", vers 11: "Modersmaalet dybt sig bøier/Let og liflig det sig føier/Efter fremmed Tankegang ". Her rettes fremmed til Herrens. Meget ofte er også hans større ændringer af høj karat. I nr. 60, "Trods Længselens Smerte", ændres vers 2 således:

Vi ere, vi bleve,

Vi røres, vi leve

I Sønnen, Guds Ord og Guds Lam; I Christus, Guds levende Ord:

Tag Ordet i Munden,

Og elsk det fra Grunden!

Saa har og saa finder du Ham! Da hos dig i Ordet han boer!

Tilsvarende omarbejdes i nr. 386 "Nu nærmer sig vor PindseFest " (efter Kingo) vers 2 således:

Rettelsen vender med vægt blikket fra de troendes vished (som også Luther kan kalde for "en urolig ting ") til Helligåndens urokkelige vidnesbyrd. 
I nr. 16, gendigtningen af "Dagvisen ", er der særlig mange rettelser, som alle øger salmens lødighed. I 1837 molesterede Grundtvig sit mesterstykke (i "Danske Høitids-Psalmer til Tusindaars Festen" 1826), hvis 13 vers alle havde rimstillingen ababcb. Han rettede nemlig (i 8 af de 10 vers, han forkortede salmen til) rimstillingen til ababab og tvang derved sig selv til en række omredigeringer, der forringede slutningen af de pågældende vers. Denne mislykkede verstekniske umage fortrød han allerede i "Psalmeblade til Kirke-Bod"(1843-44), hvor han i de vers, han da udvalgte, $i$ alt væsentligt vendte tilbage til originalens form. Fra 1847 blev salmen brugt i Vartov, fra 1851 i den form, som endelig i 1953 vandt indpas i Den danske Salmebog. I andenudgaven af Sang-Værk bevares førsteudgavens 10 vers, men de bringes næsten overalt tilbage til 1826-formen:

1837

Den signede Dag, som vi nu seer

Med Blide til os opkomme,

Den lyse paa Himlen meer og meer

Os alle til Lyst og Fromme;

Det kiendes paa os, som Barnet leer,

At Natten hun er nu omme!

Vers 9, linie 5 og 6:

Da smelter og Malm i Hjerte-Grund, Saa blegnede Kinder gløde!

Vers 10 linie 4-6:

Med Throner og gyldne Sale.

Saa frydelig der i Livets Land

Med Venner om Død vi tale!
$1868(=1826)$

Den signede Dag med Fryd vi ser

Af Havet til os opkomme

Det kiendes paa os, som Lysets Børn,

Saa tindre end maa det matte Blik, De blegnede Kinder gløde

(1826: blegnende)

Med Gammen i gyldne Sale:

Så frydelig der, til evig Tid

Med Venner i Lys vi tale!

Grundtvig indså, at førsteudgaven af Sang-Værk I bragte salmen i den ringeste af alle de former, den forelå i, og vragede derfor med sundt judicium de værste af sine kunstlede forsiringer fra 1837. Når man overvejer, om en "blivende standardudgave " bør bringe 1. eller 2. udgave af Sang-Værk I, kan det næppe være rigtigt helt at se bort fra den værdi, som næsten alle Grundtvigs rettelser i 2. udgave (1868) har.

Omtrent samtidig med udgivelsen af GSV udkom Det danske 
Sprog- og Litteraturselskabs udgave af Brorsons Samlede Skrifter ved L.J. Koch (1951-56). Han bringer ikke originaludgaven 1739 af "Troens rare Klenodie", men foretrækker ud fra en kvalitetsvurdering at følge 4. udgave 1752, den sidste som med sikkerhed daterer sig fra Brorsons levetid, og hvori digteren skonnes at have foretaget værdifulde ændringer af lignende karakter som de forandringer, Grundtvig - dokumentarisk - foretog i sit hovedværk i 1868.

En gennemprøvelse af forholdet mellem Grundtvigs to udgaver af Sang-Værk I vil efter mit skøn vise, at GSV-udgivernes "Kassation", uden nogen som helst begrundelse, af Grundtvigs velovervejede andenudgave er forkert. Det er derimod indlysende rigtigt, at GSV bringer 1870-redaktionen af Sangværkets anden del, der var så stærkt omarbejdet, at den "fremtrådte som en ganske ny bog" (se Steen Johansens Bibliografi III, s. 338). Den rummer 134 digte, hvoraf de 36 er overtaget fra første udgave. De udeladte bringes naturligvis i GSV som tillæg. Endvidere adskiller GSV II sig fra den nærmest foregående udgave af SkoleSangværket ved at udelade Grundtvigs store læredigt "Christenhedens Syvstjerne" (i Svend Grundtvigs tillæmpning). En fortrinlig nyudgave fremkom i 1955, med tekstkritisk tillæg 1956, ved Th. Balslev. Parafrase og kommentar bringes sideløbende med teksten i fodnoteform, ligesom i Begtrups udgave af "Nyaars-Morgen" (1901).

Da J. Kr. Madsen efter Grundtvigs død udgav "Salmer og aandelige Sange III (1873) og IV (1875) fulgte han Grundtvigs vilje, som var, at bd. III "skulde ordnes efter Kirkeaaret" (henføres til dets søn- og helligdage - dog er de første 24 af de 396 gengivne salmer "Ind- og Udgangssalmer") og at bd. IV skulle indholde "Salmer, der høre til Sakramenterne og til kirkelige Lejlighedshandlinger ". For den, der studerer teologien i Grundtvigs salmer, er denne tematiske gruppering i Madsens udgave stadig værdifuld.

Men for den litteraturvidenskabelige forskning er det en landvinding, at udgiverne af GSV i bd. III-V har valgt at placere salmerne kronologisk - som de oplyser: "efter formentlig Tilblivelsestid. Hvis denne ikke nøjere har kunnet bestemmes, er de anbragt i Rækken, hvor Udvalgets Flertal har fundet det rimeligt $\lll$. 
Udgiverholdets fortjeneste ligger således, for disse binds vedkommende, ikke blot i deres akribi (den nøjagtige gengivelse efter manuskript eller førstetryk), men også i deres betydelige indsats for at tidfæste salmernes tilblivelse nøjere - et arbejde, som i høj grad blev fremmet af Helge Toldbergs undersøgelser, nedfældet $\mathrm{i}$ hans afhandling fra 1946 om dateringskriterier for Grundtvigs håndskrifter (jfr. hans senere redegørelse herom $\mathrm{i}$ Registrant over N.F.S. Grundtvigs Papirer, bd. XXIX, 1964). Det viste sig bl.a., at en række tekster, hvis tilblivelse før var anslået til 1844 eller senere, er ældre (se Steen Johansens Bibliografi bd. III).

Det nu foreliggende genoptryk af GSV skæmmes desværre af nogle forsømmelighedsfejl. Forordet til bd. 3.1 henviser læseren til en fotografisk gengivelse "sidst $\mathrm{i}$ dette Bind " af originalmanuskriptet til "De levendes Land " - de fire billedsider (i 1. udg. af GSV III efter s. 539) findes slet ikke i optrykket, men er udeladt, ligesom alle 1. udgavens værdifulde fotos af håndskrifter.

Bd. 5.2 slutter med et Alfabetisk Fællesregister til hele værket, hentet fra GSV VI, men her er dog optrykket hensynsfuldt omredigeret, så der ikke henvises til det salmestof, som stiltiende er udeladt, nemlig de (ret få og fragmentariske) salmetekster, som først forekommer i det ikke-optrykte bd. VI (hvorom forordet til nævnte register s. 531, linie 5-6 -strøget i nyudgavens optryk bd. 5.2 side 640 - oplyser).

En alvorligere mangel ved genudgivelsen er, at man ikke har gjort brug af den fortegnelse over Rettelser og Tilføjelser til hele Sangværket, som blev bragt i GSV VI, s. 498 ff. Havde man givet sætteren den liste, kunne man have undgået at genoptrykke både en lang række tryk- eller læsefejl og især meningsforstyrrende ombytninger af linier (bd. 4.1, s. 27, nederste vers) og så grove fejl som udeladelse af et helt vers (bd. 4.1 mangler salmen no. 60 sidste vers). Lykkeligvis er fejl som de sidstnævnte dog kun få.

GSV kan ikke karakteriseres som den "blivende" udgave, men nok som tjenlig i de vide kredse, hvor interessen for Grundtvig er levende.

For Grundtvig-Selskabet må det være målet at gå i samarbejde med Det danske Sprog- og Litteraturselskab om en videnskabelig udgave af salmerne i stil med dette selskabs udgaver af Bror- 
son og Kingo. De to selskaber har jo allerede i fællesskab tilvejebragt "Registrant over N.F.S. Grundtvigs Papirer" (1957-64), som i så høj grad tjener forskningen til fremme. Den fuldstændige udgave af Grundtvigs Skrifter vil, ligesom Weimar-udgaven af Luthers værker, blive et langsigtet og meget langvarigt tiltag. Men det vil være naturligt at begynde med salmerne som hans hovedindsats i vor litteratur, og for denne så tiltrængte udgivelse vil det dygtige og minutiøse arbejde, som er nedlagt i GSV, være af stort værd. 